University of Nebraska - Lincoln

DigitalCommons@University of Nebraska - Lincoln

Faculty Publications from the Harold W. Manter Laboratory of Parasitology

6-1997

\title{
Eimeria from Bats of the World: Two New Species from Myotis spp. (Chiroptera: Vespertilionidae)
}

\author{
Damien T. Scott \\ University of New Mexico \\ Donald W. Duszynski \\ University of New Mexico, eimeria@unm.edu
}

Follow this and additional works at: https://digitalcommons.unl.edu/parasitologyfacpubs

Part of the Parasitology Commons

Scott, Damien T. and Duszynski, Donald W., "Eimeria from Bats of the World: Two New Species from Myotis spp. (Chiroptera: Vespertilionidae)" (1997). Faculty Publications from the Harold W. Manter Laboratory of Parasitology. 155.

https://digitalcommons.unl.edu/parasitologyfacpubs/155

This Article is brought to you for free and open access by the Parasitology, Harold W. Manter Laboratory of at DigitalCommons@University of Nebraska - Lincoln. It has been accepted for inclusion in Faculty Publications from the Harold W. Manter Laboratory of Parasitology by an authorized administrator of DigitalCommons@University of Nebraska - Lincoln. 


\title{
EIMERIA FROM BATS OF THE WORLD: TWO NEW SPECIES FROM MYOTIS SPP. (CHIROPTERA: VESPERTILIONIDAE)
}

\author{
Damien T. Scott and Donald W. Duszynski \\ Department of Biology, The University of New Mexico, Albuquerque, New Mexico 87131
}

\begin{abstract}
Between 1986 and 1995, 548 fecal samples were collected from 41 species of bats (Molossidae, Mormoopidae, Phyllostomidae, Thyropteridae, and Vespertilionidae) from New Mexico, California, Baja California Sur (Mexico), and Bolivia. Of these, the feces of $28(5 \%)$ bats, including Antrozous pallidus, Myotis ciliolabrum, Myotis lucifugus, and Myotis yumanensis (Vespertilionidae), contained oocysts representing at least 3 species of Eimeria. A new species of eimerian from M. lucifugus (3/ $27,11 \%)$ and $M$. yumanensis $(8 / 70,11 \%)$ is described. Sporulated oocysts are ellipsoidal, $22.3 \times 14.8(18-25 \times 13-16) \mu \mathrm{m}$ with micropyle $(\sim 2 \mu \mathrm{m})$ and polar granules (1-4), but an oocyst residuum is absent. The oocyst wall is slightly rough exteriorly and has 2 layers (total $\leq 1 \mu \mathrm{m}$ thick). Football-shaped sporocysts are $8.1 \times 6.6(8-11 \times 5-7) \mu \mathrm{m}$, each with a Stieda body and granular sporocyst residuum present. A new eimerian from $M$. yumanensis $(4 / 70,6 \%)$ and $M$. ciliolabrum $(1 / 12,8 \%)$ also is described. Sporulated oocysts are spheroidal to subspheroidal, $15.0 \times 14.1(14-16 \times 14-16) \mu \mathrm{m}$, with micropyle and oocyst residuum absent; a polar granule is present. The wall is smooth and has 2 layers (total $<1 \mu \mathrm{m}$ thick). Sporocysts are footballshaped, $7.1 \times 5.9(6-9 \times 5-7) \mu \mathrm{m}$, each with a Stieda body and sporocyst residuum. The sporulated oocysts of a third morphotype, found in A. pallidus $(12 / 85,14 \%)$, were indistinguishable from those of Eimeria arizonensis, a species typically found in murid rodents. The currently recognized species of bat Eimeria are listed, and a dichotomous key is provided.
\end{abstract}

Currently, there are only 15 valid eimerian species described from bats worldwide (Duszynski and Barkley, 1985; Duszynski et al., 1988, Duszynski, 1997), in comparison with $>400$ eimerians described from rodents (Levine and Ivens [1990] listed 372). This is surprising because bats are the second most diverse order of mammals with approximately 900 species (Nowak, 1994). Ubelaker et al. (1977) suggested that this low diversity of Eimeria in bats is due primarily to a lack of searching for them when bats are surveyed for parasites. However, examination of additional bats for coccidians by several authors since 1977 suggests that the overall prevalence of eimerians is generally lower in bats than in rodents. Furthermore, the prevalence of bat eimerians reported from previous surveys has been quite variable; for example, <1\% (2/400; Marinkelle, 1968 ) to $70 \%$ (105/151; Yang-Xian and Fu-Qiang, 1983). Here, we report on 3 species of Eimeria discovered while examining 548 bats representing 41 species.

\section{MATERIALS AND METHODS}

Hosts were collected as part of several chiropteran surveys (see Fig. 1 for collection localities) conducted in New Mexico (1994-1995), California (1995), Mexico (1994), and Bolivia (1986-1994); bats were caught using mist nets, trip lines, and by hand. Feces were taken from the intestines of bats that were collected for voucher specimens. All voucher specimens from the U.S.A., Mexico, and a portion of those from Bolivia are deposited in the Museum of Southwestern Biology, the University of New Mexico (MSB). Additional Bolivian voucher specimens are deposited in the American Museum of Natural History, New York, the Noel Kempff Mercado Museo, Santa Cruz, Bolivia, or in the National Museo de Historia Natural, La Paz, Bolivia. Bats that were to be released were held in captivity until they defecated into individual containers. All procedures for preserving fecal material and measuring and photographing oocysts were described earlier (Duszynski et al., 1982; Stout and Duszynski, 1983). Oocysts were less than 200 days old when measured. All measurements are in $\mu \mathrm{m}$ with the mean in parentheses following the size ranges.

\section{RESULTS}

Of the 548 bats (41 species) examined for coccidians, 28 (5\%) had eimerian oocysts in their feces (Table I). Infected

Received 28 August 1996; revised 30 December 1996; accepted 30 December 1996. species included Antrozous pallidus, Myotis ciliolabrum, Myotis lucifugus, and Myotis yumanensis. All infected bats were from southwestern North America (Table I). Three eimerian morphotypes were found. Two of these are described as new species. The third, which we choose not to name at present, is structurally identical to Eimeria arizonensis, typically found in murid rodents. Table II provides a list of bat species with valid $E i$ meria spp. and a dichotomous key to these eimerians from bats of the world is given below.

\section{Key to Eimeria of bats}

1a. Oocyst wall-rough, mammilated $\ldots \ldots \ldots \ldots \ldots \ldots 12$

1b. Oocyst wall-smooth $\ldots \ldots \ldots \ldots \ldots \ldots \ldots \ldots \ldots \ldots \ldots \ldots$

2a. Large oocyst $>36-46 \times 28-40(41 \times 35) \ldots \ldots$ E. mehelyi

2b. Small-medium oocyst $<13-30 \times 13-30 \ldots \ldots \ldots \ldots \ldots$

3a. Micropyle present $\ldots \ldots \ldots \ldots \ldots \ldots \ldots \ldots$

3b. Micropyle absent $\ldots \ldots \ldots \ldots \ldots \ldots \ldots \ldots \ldots \ldots$

4a. Polar granules absent $\ldots \ldots \ldots \ldots \ldots \ldots \ldots$ levinei

4b. Polar granules present $\ldots \ldots \ldots \ldots \ldots \ldots$. andamanensis

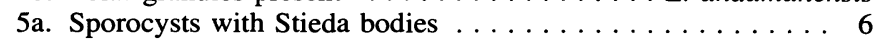

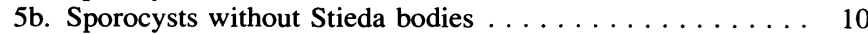

6a. Oocyst wall(s) - thick $(3 \mu \mathrm{m}) \ldots \ldots \ldots \ldots \ldots$. vespertilli

6b. Oocyst wall(s)-thin $(<3 \mu \mathrm{m}) \ldots \ldots \ldots \ldots \ldots \ldots \ldots$

7a. Polar granules present $\ldots \ldots \ldots \ldots \ldots \ldots \ldots \ldots$

7b. Polar granules absent . . . . . . . . E. rhynchonycteridis

8a. Oocysts spherical (14-16 $\times 14-16)$; Sporozoites with refractile bodies at posterior end . . . . . . . . E. pilarensis

8b. Oocysts not spherical, larger than E. pilarensis . . . . . . . .

9a. Inner wall wrinkled, sporocyst residuum composed of dispersed granules . . . . . . . . . . E. kunmingensis

9b. Inner wall smooth, sporocyst residuum composed of fine granules (not dispersed, diameter $\sim 3.5) \ldots \ldots \ldots \ldots$. vejsovi

10a. Polar granules present $\ldots \ldots \ldots \ldots \ldots$. zakirica

10b. Polar granules absent $\ldots \ldots \ldots \ldots \ldots \ldots \ldots \ldots \ldots \ldots$

11a. Large oocyst residuum present $\ldots \ldots \ldots \ldots \ldots$. . dukei

11b. Oocyst residuum absent $\ldots \ldots \ldots \ldots \ldots \ldots \ldots$. hessei

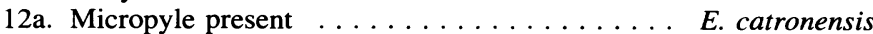

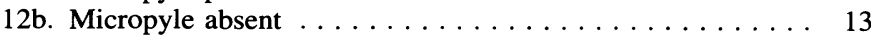

13a. Sporocysts with substieda bodies $\ldots \ldots \ldots \ldots \ldots \ldots 14$

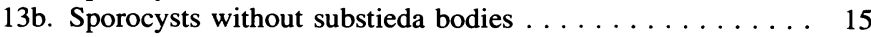

14a. Oocyst residuum and/or polar granules present but variable .. $\ldots \ldots \ldots \ldots \ldots \ldots \ldots \ldots \ldots \ldots \ldots \ldots \ldots \ldots$ tadarida ${ }^{*}$

* Duszynski et al. (1988) were not sure whether the dispersed granules were polar granules or part of an oocyst residuum. 
14b. Oocyst residuum absent $\ldots \ldots \ldots \ldots \ldots \ldots \ldots$. macyi $\dagger$

15a. Oocyst residuum present $\ldots \ldots \ldots \ldots \ldots$

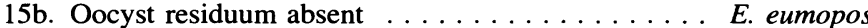

16a. Oocyst medium to large $(26-34 \times 20-28) \ldots \ldots$. . tomopea

16b. Oocyst small $(16-25 \times 14-21) \ldots \ldots \ldots \ldots$. . . . . . E Ekeri

\section{Eimeria pilarensis n. sp.}

(Figs. 2-4, 12)

Diagnosis: Oocyst wall $\leq 1$ thick, consisting of 2 layers of approximately equal thickness; outer, yellowish, smooth; inner, dark, smooth; micropyle and oocyst residuum absent, but polar granule present; sporulated oocysts $(n=30)$ spheroidal to subspheroidal (Figs. 2-4) 14-16 $\times 14-16(15.0 \times 14.1)$ with $\mathrm{L}: \mathrm{W}$ ratio $1.0-1.2(1.1)$; sporocysts ovoidal to subspheroidal (Figs. 3, 4) 6-9 $\times 5-7(7.1 \times 5.9)$, with L:W ratio 1.1-1.5 (1.2); Stieda body present (Fig. 2), but sub- and parastieda bodies absent. Sporocyst residuum composed of singular, refractile mass ( 2, Fig. 4), or dispersed granules obscuring sporozoites. Sporozoites have a spheroidal, posterior refractile body.

\section{Taxonomic summary}

Symbiotype: Myotis ciliolabrum Audubon and Bachman, 1842, small-footed myotis.

Other hosts: Myotis yumanensis H. Allen, 1864, Yuma myotis.

Type locality: U.S.A., New Mexico, Taos Co., Pilar, Orilla Verde (3 in Fig. 1a).

Other localities: M. yumanensis: U.S.A., California, San Luis Obispo Co., Camp Roberts, Twin Bridges $35^{\circ} 46.1^{\prime} \mathrm{N}, 120^{\circ} 50.9^{\prime} \mathrm{W}$ (12 in Fig.

1a) and New Mexico, Catron Co., Gila National Forest (10 in Fig. 1a).

Prevalence: Myotis ciliolabrum: 1/12 (8\%) in New Mexico (all localities); M. yumanensis: $3 / 41$ (7\%) in California (all localities) and 1/29 (3\%) in New Mexico (all localities).

Site of infection: Unknown. Oocysts collected from feces.

Material deposited: Phototype (see Bandoni and Duszynski, 1988) of sporulated oocysts in the USNPC no. 86938. Symbiotype (see Frey et al., 1992): M. ciliolabrum in the MSB (NK 32306, male), A. R. Deans no. 009, 22 June 1995.

Etymology: The nomen triviale is derived from the name of the town that is nearest to where the symbiotype was collected and -ensis (L., belonging to).

\section{Remarks}

Eimeria pilarensis is most similar to Eimeria vejsovi Cerná, 1976 and Eimeria kunmingensis Yang-Xian and Fu-Qiang, 1983, except that $E$. pilarensis is smaller than $E$. vejsovi $(15 \times 14$ vs. $21 \times 18)$ and $E$. kunmingensis has an inner wall that is wrinkled. Also, E. pilarensis differs from all New World bat eimerians except $E$. rhynconyteridis Lainson, 1968 by having a smooth wall. However, E. rhynconycteridis is larger $(25.5=$ diameter $)$ and has a wall with 1 obvious layer versus 2 layers in E. pilarensis.

\section{Eimeria catronensis n. sp.}

(Figs. 5-9, 13)

Diagnosis: Oocyst wall $\leq 1$ thick, consisting of 2 layers of approximately equal thickness; outer, yellowish and rough (best seen with Nomarski interference contrast optics), inner, dark and smooth; micropyle ( $\sim 2$ wide) position variable (Figs. 7-9), usually assymetrically located near more pointed end of oocyst (Fig. 7), not present in unsporulated oocysts (Fig. 9); 1-4 polar granules present (Fig. 5), but oocyst residuum absent. Sporulated oocysts $(\mathrm{n}=30$ ) ovoidal (Figs. 5, 6) $18-25 \times$ 14-17 $(22.2 \times 14.8)$ with $\mathrm{L}: \mathrm{W}$ ratio $1.5(1.3-1.7)$, sporocysts footballshaped (Fig. 6) 8-11 $\times 5-7(8.1 \times 6.6)$, with L:W ratio $1.2(1.1-1.8)$, Stieda body present (Fig. 6), but sub- and parastieda bodies absent. Sporocyst residuum consists of a granular mass often obscuring sporozoites (Fig. 6)

\section{Taxonomic summary}

Symbiotype: Myotis lucifugus Le Conte, 1831, little brown bat Other hosts: Myotis yumanensis H. Allen, 1864, Yuma myotis.

$\dagger$ Wheat (1975) described this eimerian with 1 wall and 1 membrane, his description could easily be interpreted as 2 walls
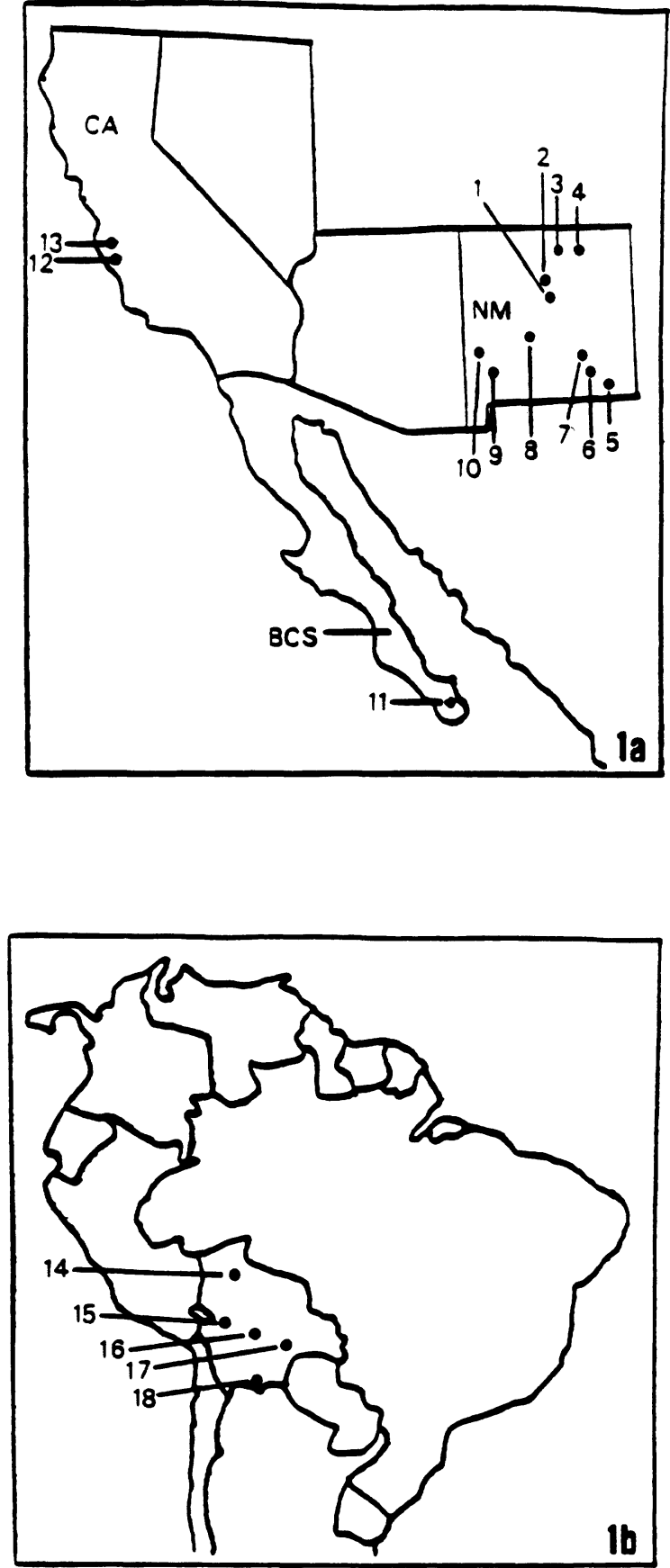

Figure 1. a. Map of New Mexico, California, and Baja California Sur (Mexico): Bernalillo Co., NM (1), Sandoval Co., NM (2), Rio Arriba Co., NM (3), Taos Co., NM (4), Eddy Co., NM (5), Otero Co., NM (6) Lincoln Co., NM (7), Socorro Co., NM (8), Grant Co, NM (9), Catron Co., NM (10), Rancho Burreras, BCS (11), Camp San Luis Obispo, CA (12), Camp Roberts, CA (13). b. Map of South America: Beni, Bolivia (14) La Paz, Bolivia (15), Cochabamba, Bolivia (16), Santa Cruz, Bolivia (17), Tarija, Bolivia (18).

Type locality: U.S.A., New Mexico, Catron Co., Gila National Forest, Bill Lewis Cienega, $33^{\circ} 27.6^{\prime} \mathrm{N}, 108^{\circ} 37.9^{\prime} \mathrm{W}$ (10 in Fig. 1a).

Other localities: Myotis lucifugus and M. yumanensis: New Mexico, Catron Co., Gila National Forest, Sheep Springs, $33^{\circ} 25.4^{\prime} \mathrm{N}$ $108^{\circ} 32.98^{\prime} \mathrm{W}$ (10 in Fig. 1a)

Prevalence: Myotis lucifugus: $3 / 27(11 \%)$ in New Mexico (all localities), M. yumanensis: 8/29 (28\%) in New Mexico (all localities). 
TABle I. List of the bats from New Mexico, California, Baja California Sur (Mexico), and Bolivia that were examined for coccidians.

\begin{tabular}{|c|c|c|}
\hline Host & $\begin{array}{c}\text { Locality } \\
\text { (nos. in Fig. 1) }\end{array}$ & $\begin{array}{c}\text { No. hosts } \\
\text { infected/no. } \\
\text { examined } \\
(\%)\end{array}$ \\
\hline \multicolumn{3}{|l|}{ Mollosidae } \\
\hline Molossus molossus & $15,16,18$ & $0 / 12$ \\
\hline Nyctinomops macrotus & 2,5 & $0 / 4$ \\
\hline Tadarida brasiliensis & $5,13,16$ & $0 / 20$ \\
\hline \multicolumn{3}{|l|}{ Mormoopidae } \\
\hline Mormoops megalophyla & 11 & $0 / 1$ \\
\hline \multicolumn{3}{|l|}{ Phyllostomidae } \\
\hline Anoura geoffroyi & 15,17 & $0 / 3$ \\
\hline Artibeus anderseni & 16 & $0 / 1$ \\
\hline Artibeus lituratus & 16 & $0 / 7$ \\
\hline Artibeus obscurus & 16 & $0 / 3$ \\
\hline Artibeus planirostris & 16 & $0 / 5$ \\
\hline Carollia brevicauda & 16 & $0 / 1$ \\
\hline Carollia perspicillata & 16 & $0 / 1$ \\
\hline Macrophyllum macrophyllum & 16 & $0 / 1$ \\
\hline Phyllostmus hastatus & 14 & $0 / 1$ \\
\hline Platyrhinus infuscus & 16 & $0 / 1$ \\
\hline Pygoderma sp. & 17 & $0 / 1$ \\
\hline Sturnira erythromos & 15,17 & $0 / 2$ \\
\hline Sturnira lilium & 15 & $0 / 1$ \\
\hline Sturnira oporaphilum & 16 & $0 / 1$ \\
\hline Tonatia sylvicola & 16 & $0 / 1$ \\
\hline Uroderma sp. & 17 & $0 / 1$ \\
\hline \multicolumn{3}{|l|}{ Thyropteridae } \\
\hline Thyroptera $\mathrm{sp}$. & 14 & $0 / 1$ \\
\hline \multicolumn{3}{|l|}{ Vespertilionidae } \\
\hline Antrozous pallidus & $1,2,6,7,11$ & $12 / 85(14)$ \\
\hline Eptesicus fuscus & $2,5,7,8,12,13$ & $0 / 81$ \\
\hline Eptesicus brasiliensis & 18 & $0 / 1$ \\
\hline Euderma maculatum & 7 & $0 / 2$ \\
\hline Lasionycteris noctivagans & $3,7,10$ & $0 / 60$ \\
\hline Lasiurus blossevilli & $8,11,15$ & $0 / 4$ \\
\hline Lasiurus cinereus & $3,5,8,13$ & $0 / 31$ \\
\hline Myotis albescens & 18 & $0 / 3$ \\
\hline Myotis auriculus & 9,10 & $0 / 10$ \\
\hline Myotis californicus & 12,13 & $0 / 15$ \\
\hline Myotis ciliolabrum & $4,5,8,10$ & $1 / 12(8)$ \\
\hline Myotis evotis & $3,8,10$ & $0 / 13$ \\
\hline Myotis lucifugus & $3,7,9,10$ & $3 / 27(11)$ \\
\hline Myotis oxyotus & 16 & $0 / 3$ \\
\hline Myotis thysanodes & 3,10 & $0 / 15$ \\
\hline Myotis velifer & 3 & $0 / 3$ \\
\hline Myotis volans & $3,5,10$ & $0 / 30$ \\
\hline Myotis yumanensis & $3,10,12,13$ & $12 / 70(17)$ \\
\hline Pipistrellus hesperus & 4,5 & $0 / 12$ \\
\hline Plecotus towsendii & 4,5 & $0 / 2$ \\
\hline 5 families, 41 species & 18 localities & $28 / 548(5)$ \\
\hline
\end{tabular}

Site of infection: Unknown. Oocysts collected from feces.

Materials deposited: Phototype of sporulated oocyst in the USNPC no. 86938. Symbiotype: Myotis lucifugus in the MSB (NK 27793), 144 P. Case (RGZ), 9 August 1995; parasymbiotypes: NK 14883, female, 584 D. T. Scott, 8 August 1995, NK 14884, female, 585 D. T. Scott, 8 August 1995; NK 32253.

Etymology: The nomen triviale is derived from the county where the symbiotype was collected and -ensis (L., belonging to).

\section{Remarks}

Eimeria catronensis differs from all other bat eimerians except Eimeria andamanensis Mandal and Nair, 1973 and Eimeria levinei Bray, 1958 by having a micropyle. However, E. catronensis differs from these by having a rough wall. Also, $E$. catronensis differs from $E$. andamanensis by being ellipsoidal rather than spheroidal to subspheroidal and has 1-4 polar granules whereas $E$. levinei has none.

\section{Eimeria sp. (E. arizonensis-like)}

(Figs. 10, 11)

Sporulated oocysts $(\mathrm{n}=75)$ of Eimeria sp. match previous descriptions of $E$. arizonensis (Levine et al., 1957; Reduker et al., 1985) qualitatively and quantitatively (Table III).

\section{Taxonomic summary}

Host: Antrozous pallidus Le Conte, 1854.

Localities: Mexico, Baja California Sur (BCS), Rancho Burreras, $23^{\circ} 25.71^{\prime} \mathrm{N}, 110^{\circ} 6.95^{\prime} \mathrm{W}$, elevation: $420 \mathrm{~m}$ (11 in Fig. 1a); New Mexico, Eddy Co., Lincoln National Forest, Guadalupe District, Wild Horse Well (5 in Fig. 1a).

Prevalence: Six of 11 (55\%) from Eddy Co., New Mexico (NM), 6 of $8(75 \%)$ from Baja California Sur and 12 of 85 (14\%) from all localities.

\section{Remarks}

The high prevalence in Eddy Co., NM and BCS, Mexico suggests that this may not be a spurious infection. This eimerian was not named however, because of its close similarity to E. arizonensis (see below). If further research proves that this eimerian is E. arizonensis, it will be the first report of an eimerian naturally infecting 2 orders of mammals, although Hendricks (1977) was able to infect carnivores and didelphimorphs with Isospora arctopitheci Rodhain, a primate coccidian.

\section{DISCUSSION}

The factors that contribute to the prevalence of eimerians in vertebrates include host specificity, acquired immunity, and several abiotic factors (Marquardt et al., 1960; Todd and Hammond, 1968; Wilber et al., 1994). Wilber et al. (1994) suggested that ultraviolet radiation and humidity drive the patterns seen in the prevalence of eimerians in Townsend's ground squirrels (Spermophilus townsendii) in Idaho. Although no one has demonstrated it empirically, the abiotic factors most likely to contribute to the infection of bats by eimerians are the stability of the roost microclimate, i.e., relative humidity and temperature, and roosting behavior by bats, i.e., colonial vs. solitary. For example, bats that prefer crowded roosts with stable microclimates, e.g., maternity colonies in attics and caves, may be more likely to ingest sporulated oocysts than bats that prefer to roost alone where microclimates may be highly variable, e.g., trees and leaf litter. Compact roost types, such as crevices and attics, may bring bats into contact with feces more often than large, open roosts, such as caves. Bats that choose these compact roosts may have a greater prevalence of eimerians than bats that choose the larger, open roosts, due to continued contact with feces. Likewise, increased grooming that occurs within maternity colonies may contribute to a greater chance of bats ingesting infective oocysts.

The overall prevalence of eimerians in bats appears to be low relative to other mammals. The 2 largest surveys of bats for coccidians demonstrated prevalences of $<1 \%$ (2/400; Marinkelle, 1968) and 5\% (28/548, present study), whereas, for example, a similar-sized survey of southwestern rodents for coccidians found a prevalence of 29\% (104/361; Stout and Duszynski, 1983). However, in some bat species such as $A$. pal- 
TABLE II. Bats with valid Eimeria spp. from the world.

\begin{tabular}{|c|c|c|c|}
\hline Host & Locality & Eimeria spp. & Citation \\
\hline \multicolumn{4}{|l|}{ Emballonuridae } \\
\hline Rhynchonecteris naso & Belize, Central America & rhynchonycteridis & Lainson (1968) \\
\hline Taphozous melanopogon & Andaman Island, India & andamanensis & Mandal and Nair (1973) \\
\hline Taphozous nudiventris & Egypt, North Africa & dukei & Černá and Ryšavý (1976) \\
\hline \multicolumn{4}{|l|}{ Molossidae } \\
\hline $\begin{array}{l}\text { Eumops perotis } \\
\quad(=E . \text { trumbulli })\end{array}$ & Colombia, South Africa & eumopos & Marinkelle (1968) \\
\hline $\begin{array}{l}\text { Chaerephon (=Tadarida) bem- } \\
\text { melini }\end{array}$ & Liberia, West Africa & levinei & Bray (1958) \\
\hline Chaerephon pumila & Uganda, Central Africa & dukei & Lavier (1927) \\
\hline Nyctinomops femorasaccus & Mexico, Central America & tadarida & Duszynski et al. (1988) \\
\hline \multicolumn{4}{|l|}{ Rhinolophidae } \\
\hline Rhinolophus hipposideros & France, Western Europe & hessei & Lavier (1924) \\
\hline Rhinolophus mehelyi & Azerbaidzhan, Eastern Europe & mehelyi & Musaev and Gauzer (1971) \\
\hline \multicolumn{4}{|l|}{ Vespertilionidae } \\
\hline Antrozous pallidus & $\begin{array}{l}\text { Mexico, Central America and USA, } \\
\text { North America }\end{array}$ & arizonensis-like & Present study \\
\hline Myotis lucifugus & USA, North America & catronensis & Present study \\
\hline Myotis ciliolabrum & USA, North America & pilarensis & Present study \\
\hline Myotis ricketi & Japan, Asia & kunmingensis & Yang-Xian and Fu-Qiang (1983) \\
\hline Myotis yumanensis & USA, North America & $\begin{array}{c}\text { catronensis/ } \\
\text { pilarensis }\end{array}$ & Present study \\
\hline Nyctalus noctula & $\begin{array}{l}\text { Czechoslovakia, Eastern } \\
\text { Europe }\end{array}$ & vejsovi & Černá (1976) \\
\hline $\begin{array}{l}\text { Pipistrellus javanicus } \\
\quad(=P . \text { abramus })\end{array}$ & China, Asia & redukeri & Duszynski (1997) \\
\hline Pipistrellus subflavus & USA, North America & macyi & Wheat $(1975)$ \\
\hline Tomopeas ravus & Peru, South America & tomopea & Duszynski and Barkley (1985) \\
\hline Vespertillio murinus & Azerbaidzhan, Eastern Europe & vespertilii & Musaev and Veisov (1961) \\
\hline$V$. murinus $(=V$. kuhlii $)$ & Azerbaidzhan, Eastern Europe & zakirica & Musaev (1967) \\
\hline
\end{tabular}

lidus, a colonial roosting bat, the prevalence of eimerians is $>50 \%$ (present study). In the summer months, pallid bats form maternity colonies where self-grooming and allo-grooming may increase the potential for ingesting infective oocysts. However, not all colonial bats have a high prevalence of eimerians. For example, Eptesicus fuscus, also a colonial bat, had no eimerians.

Eimeria arizonensis has been reported in Peromyscus maniculatus, $P$. eremicus, $P$. truei, Reithrodontomys megalotus, $R$. montanus, and Onychomys leucogaster (Levine et al., 1957; Reduker et al., 1985; Duszynski et al., 1992). The form we found in A. pallidus is strikingly similar, both quantitatively and qualitatively, to the previous descriptions of E. arizonensis (Table III). The occurrence of an E. arizonensis-like eimerian in $A$. pallidus is puzzling, but not without precedent. For example, Couch et al. (1997) recently reported another E. arizonensislike species in an Old World rodent, Acomys cahirinus (Muridae). They argued that given the difference in continents and host subfamilies (sensu Wilson and Reeder, 1993) that the form they described was likely a new species. The $E$. arizonensislike form that we report may also be a new species because it crossed not only subfamily but ordinal boundaries. Thus, there may be some, as yet not understood, advantage to the $E$. arizonensis body plan (sporulated oocyst) that has resulted in a convergent complex of similar species. It is also possible that $E$. arizonensis may be a generalist that has been successful in infecting hosts from different orders of mammals as can some isosporan species (Hendricks, 1977). Finally, and least likely, is that the form in A. pallidus may occur only spuriously in bats. Molecular and reinfection studies are needed to determine the exact status of the $E$. arizonensis-like eimerian occurring in pallid bats and for these reasons, we have not created a new name at this time.

It is interesting to note that $A$. pallidus regularly lands on the ground to feed on large insects such as millipedes, scorpions, ground crickets, and beetles (Hermanson and O'Shea, 1983). This behavior may bring pallid bats in regular contact with rodent feces carrying infective $E$. arizonensis oocysts. If this occurs then there are 2 possible outcomes. Either E. arizonensis has been able to adapt to the gut cells of A. pallidus and produce a viable infection resulting in the discharge of new oocysts or the sporulated $E$. arizonensis oocysts simply pass through the bat unharmed and, when found in the feces, represent a spurious infection. Also, A. pallidus occasionally will eat vertebrates such as the lizard, Phrynosoma douglassi, and the heteromyid rodent, Perognathus flavus (O' Shea and Vaughn, 1977; Bell, 1982). If a pallid bat were to eat a murid rodent of similar size, i.e., Reithrodontomys spp., it could be infected with $E$. arizonensis spuriously. This mode of infection is doubtful because this coccidian occurred in such high prevalence in 2 localities, Rancho Burreras, BCS Mexico $(6 / 8,75 \%)$ and Lincoln Co., NM $(6 / 11,55 \%)$. In addition, the main diet of pallid bats consists of insects, not rodents (Hermanson and O' Shea, 1983). 

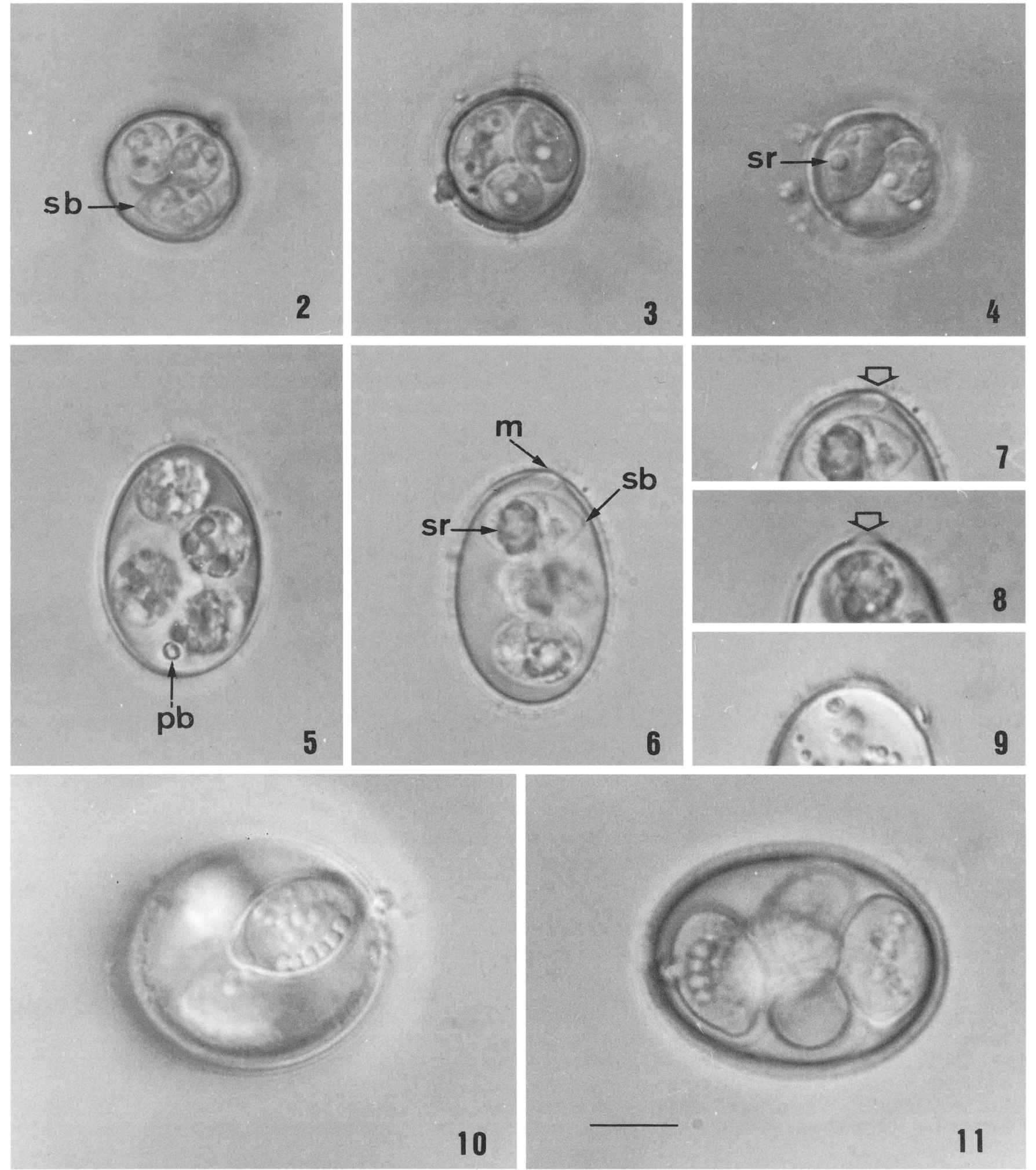

FIGURES 2-11. Photomicrographs of sporulated oocysts of various Eimeria species from bats. 2-4. Eimeria pilarensis n. sp. 5-9. Eimeria catronensis n. sp. Note differences in location of micropyle (arrows) in Figures 7 and 8 and apparent absence of micropyle in unsporulated oocyst (Fig. 9). 10, 11. Eimeria sp. (E. arizonensis-like). Scale bar $=10 \mu \mathrm{m}$ for all figures; m, micropyle; pb, polar body; sb, Stieda body; sr, sporocyst residuum. 

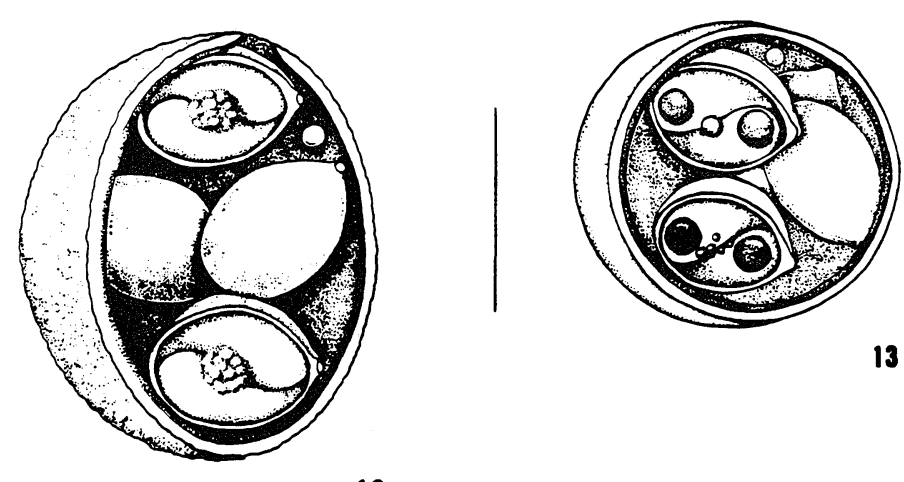

13

12

FIGURES 12, 13. Composite line drawings of sporulated oocysts of eimerians collected from the feces of vespertilionid bats. 12. Eimeria catronensis. 13. Eimeria pilarensis. Scale bar $=10 \mu \mathrm{m}$.

If Duszynski et al. (1988) are correct in assuming there may be as many as 850 species of Eimeria in bats, then the current number of described bat eimerians represents only $2 \%$ of the total. This may be due to the few bat species examined and the limited geographic coverage of studies that have surveyed bats for coccidians. It is possible that coccidia are rare in bats making them more difficult to find. However, since only about 1,400 bats ever have been examined for coccidians (present study included), determinations about the overall prevalence of bat coccidial infections cannot be made.

The present paper differs from previous reviews (Wheat, 1975; Levine and Ivens, 1981; Duszynski and Barkley, 1985; Duszynski et al., 1988) in that it provides a dichotomous key, and includes 2 new species described since the 1988 review (Duszynski et al., 1988). We did not address 3 named species in this review, E. viridis, E. plecoti, and E. myotis, because they were considered nomina nuda by others (Wheat, 1975; Duszynski and Barkley, 1985; Duszynski et al., 1988). However, species inquirenda, defined by Ride et al. (1985) as "a doubtfully identified species needing further investigation," is a more appropriate term. We propose that E. nyctali Gottschalk, 1974 also be considered a species inquirenda because (1) it appears to have been described from a partially sporulated oocyst; (2) its description is based on indistinct characteristics shown in a line drawing; and (3) it has a sporulation time of only $24 \mathrm{hr}$
(Gottschalk, 1974), whereas the average sporulation time for other bat eimerians is usually $\geq 1 \mathrm{wk}$. In fact, $E$. nyctali may have been a partially sporulated oocyst of $E$. vejsovi (also found in Nyctalus noctula in eastern Europe), but without examining the fully sporulated oocyst, $E$. nyctali can only be considered a species inquirenda.

Duszynski and Barkley (1985) and Duszynski et al. (1988) suggest that there may be 2 independent eimerian lineages that infect vespertilionid and molossid bats. This hypothesis suggests that eimerians infecting Old World bat species have a smooth outer oocyst wall and those infecting New World bat species have a rough outer wall. However, E. pilarensis, which infects $M$. ciliolabrum and $M$. yumanensis (New World vespertilionids), has a smooth wall. In addition, Eimeria redukeri Duszynski, 1996, which infects Pipistrellus javanicus (Gray) of Japan, has a rough wall. If there is a split between these 2 eimerian lineages, the texture of the wall does not appear to be the determinant factor.

\section{ACKNOWLEDGMENTS}

We are grateful to J. A. Hnida, P. G. Wilber and J. K. Frey for reviewing earlier drafts of the manuscript, to Beth Dennis for the line drawings, and to M. A. Bogan for verifying the identifications of the symbiotypes. We also thank W. L. Gannon, T. W. Perry, S. R. Davenport, A. R. Deans, A. G. Hawk, J. Hazleton, M. Saenz and many others for field and laboratory assistance. The Museum of Southwestern Biology provided technical and curatorial support. This work was supported in part by an NSF-PEET grant (DEB-9521687, D.W.D.), New Mexico Department of Game and Fish, Share with Wildlife, Bureau of Land Management, and U.S. Forest Service (Lincoln National Forest and Gila National Forest) contracts to W. L. Gannon.

\section{LITERATURE CITED}

BANDONI, S., AND D. W. Duszynski. 1988. A plea for improved presentation of type material for coccidia. Journal of Parasitology 74: 519-523.

BELL, G. P. 1982. Behavioral and ecological aspects of gleaning by a desert insectivorous bat, Antrozous pallidus (Chiroptera: Vespertilionidae). Behavioral Ecology and Sociobiology 10: 217-223.

BRAY, R. S. 1958. On the parasitic protozoa of Liberia. I. Coccidia of some small mammals. Journal of Protozoology 5: 81-83.

TABLE III. Comparison of Eimeria arizonensis oocysts from rodents to E. arizonensis-like oocysts from pallid bats (this study) for 7 quantitative characters. Presented are average values for each trait.

Eimeria arizonensis or E. arizonensis-like oocysts: hosts

\begin{tabular}{lccccc} 
& \multicolumn{5}{c}{ Eimeria arizonensis or E. arizonensis-like oocysts: hosts } \\
\cline { 2 - 6 } \multicolumn{1}{c}{ Characters } & $\begin{array}{c}\text { A. pallidus } \\
(\mathrm{n}=75)^{*}\end{array}$ & $\begin{array}{c}P . \text { eremicus } \\
(\mathrm{n}=106) \dagger\end{array}$ & $\begin{array}{c}P . \text { truei } \\
(\mathrm{n}=188)\end{array}$ & $\begin{array}{c}\text { P. maniculatus } \\
(\mathrm{n}=184)\end{array}$ & $\begin{array}{c}R . \text { megalotis } \\
(\mathrm{n}=70) \ddagger\end{array}$ \\
\hline Oocyst length (L) & 25.0 & 24.3 & 23.3 & 23.6 & 26.7 \\
Oocyst width (W) & 21.4 & 21.0 & 20.6 & 21.0 & 22.7 \\
Sporocyst length (L) & 11.7 & 10.9 & 11.7 & 13.1 & 1.9 \\
Sporocyst width (W) & 7.8 & 7.5 & 7.5 & 1.1 & 8.9 \\
Oocyst L:W & 1.2 & 1.2 & 1.1 & 1.6 & 1.2 \\
Sporocyst L:W & 1.5 & 1.5 & 1.5 & 1.4 & 1.3 \\
Oocyst wall width & 1.2 & 1.5 & & Not given \\
\hline
\end{tabular}

* This study.

$\dagger$ Peromyscus eremicus, P. truei, and P. maniculatus from Reduker et al. (1985)

$\ddagger$ From Duszynski et al. (1992). 
Couch, L., L. Blaustein, D. W. Duszynski, G. Shenbrot, and E. Nevo. 1997. A new coccidian in Acomys cahirinus Desmarest, 1819 from Lower Nahal Oren, Mount Carmel, Israel. Journal of Parasitology 83: 276-279.

CERNÁ, Z. 1976. Eimeria vejsovi sp. $\mathrm{n}$. from the bat Nyctalus noctula. Folia Parasitologica (Praha) 23: 187-191.

- AND B. RYSAVY. 1976. Notes on the distribution of Eimeria dukei Lavier, 1927 in African bats. Folia Parasitologica (Praha) 23: 286.

DUSZYNSKI, D. W. 1997. Coccidia from bats (Chiroptera) of the world: A new Eimeria species in Pipistrellus javanicus from Japan. Journal of Parasitology 83: 280-282.

- AND L. J. BARKLEY. 1985. Eimeria from bats of the world: A new species in Tomopeas ravus from Peru. Journal of Parasitology 71: 204-208.

- G. EASTham, AND T. L. YATES. 1982. Eimeria from jumping mice (Zapus spp.): A new species and genetic and geographical features of $Z$. hudsonicus luteus. Journal of Parasitology 68: 11461148.

—, M. J. PAtRICK, L. Couch, AND S. J. UPTON. 1992. Eimerians in harvest mice, Reithrodontomys spp., from Mexico, California and New Mexico, and phenotypic plasticity in oocysts of Eimeria arizonensis. Journal of Protozoology 39: 644-648.

- D. W. ReduKeR, AND B. B. PARKER. 1988. Eimeria from bats of the world. II. A new species in Tadarida femorosacca from Sonora, Mexico. Journal of Parasitology 74: 317-322.

Frey, J. K., T. L. Yates, D. W. Duszynski, W. L. GanNon, and S. L. GARDNER. 1992. Designation and curatorial management of type host specimens (symbiotypes) for new parasite species. Journal of Parasitology 78: 930-932.

GotTSCHALK, C. 1974. Eine neue Kokzidienart aus dem Abendsegler (Nyctalus noctula). Angewandte Parasitologie, Jena 15: 3-5.

HENDRICKS, L. D. 1977. Host range of the primate coccidian, Isospora arctopitheci Rodhain 1933 (Protozoa: Eimeriidae). Journal of Parasitology 63: 32-35.

Hermanson, J. W., AND J. O'Shea. 1983. Antrozous pallidus. Mammalian Species Account No. 213, American Society of Mammalogists, p. 1-8.

LaINSON, R. 1968. Parasitological studies in British Honduras. III. Some coccidian parasites of mammals. Annals of Tropical Medicine and Parasitology 62: 252-259.

LAVIER, G. 1924. Eimeria hessei n. sp., coccidie intestinale de Rhinolophus hipposideros. Annales de Parasitologie humaine et Comparée, Paris 2: 335-339.

- 1927. Eimeria dukei n. sp., coccidie parasite intestinal de Chéiroptère. Comptes Rendus des Seances de la Société de Biologie et de ses Filiales et Associées, Paris 97: 1707-1709.

LEVINE, N. D., AND V. IVENS. 1981. The coccidian parasites (Protozoa, Apicomplexa) of bats. In Parasitological topics: A presentational volume to P. C. C. Garnham, F.R.S., on the occasion of his 80th birthday, E. U. Canning (ed.). Society of Protozoologists, Special Publication No. 1, Allen Press, Inc., Lawrence, Kansas, p. 170176.

-, AND —. 1990. The coccidian parasites of rodents. CRC press, Boca Raton, Florida, 228 p.
, - AND F.J. KRUIDENIER. 1957. New species of Eimeria from Arizona rodents. Journal of Protozoology 4: 80-88.

MANDAL, A. K., AND K. N. NaIR. 1973. A new species of coccidium from Taphozous melanopogon Temminek (Mammalia: Chiroptera) from Andaman Islands. Proceedings of the Indian Academy of Sciences, Section B 77: 243-246.

Marinkelle, C. J. 1968. Eimeria eumopos n. sp. from a Colombian bat Eumops trumbulli. Journal of Protozoology 15: 57-58.

Marquardt, W. C., C. M. Senger, AND L. Seghetti. 1960. The effect of physical and chemical agents on the oocyst of Eimeria zurnii (Protozoa, Coccidia). Journal of Protozoology 7: 186-189.

MusaEv, M. A. 1967. New coccidium species from Vespertillio kuhlii Kuhl. Izvestiia Akademii Nauk Azerbaidzhan SSR 5: 37.

, AND M. E. GAUZER. 1971. Eimeria mehelyi, a new species of coccidium from Rhinolophus mehelyi. Izvestiia Akademii Nauk Azerbaidzhan SSR 2: 94-96.

- , AND A. M. VeIsov. 1961. New coccidium species from Vespertillio kuhlii Kuhl. Doklady Akademii Nauk Azerbaidzan SSR 17: 741-743.

NowaK, R. M. 1994. Walker's bats of the world. The John Hopkins Press, Ltd., London, U.K., 287 p.

O'SheA, J., AND T. A. VAughn. 1977. Nocturnal and seasonal activities of the pallid bats, Antrozous pallidus. Journal of Mammalogy 58: 269-284.

Reduker, D. W., L. Hertel, and D. W. Duszynski. 1985. Eimeria species (Apicomplexa: Eimeriidae) infecting Peromyscus rodents in the southwestern United States and northern Mexico with description of a new species. Journal of Parasitology 71: 604-613.

Ride, W. D. L., C. W. Sabrosky, G. Bernardi, and R. V. Melville (eds.). 1985. International code of zoological nomenclature, 3rd. ed. H. Charlesworth and Co. Ltd., Huddersfield, U.K., 338 p.

Stout, C. A., AND D. W. DusZYNSKI. 1983. Coccidia from kangaroo rats (Dipodomys spp.) in the western United States, Baja California, and northern Mexico with descriptions of Eimeria merriami sp. $\mathrm{n}$. and Isospora sp. Journal of Parasitology 69: 209-214.

TodD, K. S., JR., AND D. M. HAMmOND. 1968. Life cycle and host specificity of Eimeria callospermophili Henry, 1932 from the Uinta ground squirrel Spermophilus armatus. Journal of Protozoology 15: $1-8$.

UbelaKer, J. E., R. D. SPECIAN, AND D. W. DuSzYNSKi. 1977. Endoparasites. In Biology of bats of the New World family Phyllostomidae, Part II, R. J. Baker, J. K. Jones, and D. C. Carter (eds.). Special Publications, The Museum, Texas Tech University, Texas Tech Press, Lubbock, Texas, p. 7-56.

WheAt, B. E. 1975. Eimeria macyi sp. n. (Protozoa: Eimeriidae) from the eastern pipistrelle, Pipistrellus subflavus, from Alabama. Journal of Parasitology 61: 920-922.

Wilber, P. G., B. Hanelt, B. Van HoRne, and D. W. Duszynski. 1994. Two new species and temporal changes in the prevalence of eimerians in a free-living population of Townsend's ground squirrels (Spermophilus townsendii) in Idaho. Journal of Parasitology 80: 251-259.

WiLson, D. E., AND D. M. REEDER (eds.). 1993. Mammal species of the world, 2nd ed., Smithsonian Institution Press, Washington, D.C., p. 501-755.

YANG-XIAN, Z., AND C. FU-QIANG. 1983. A new species of the genus Eimeria (Sporozoa: Eimeriidae) from Myotis ricketti Thomas. Acta Zootaxonomica Sinica 8: 1-3. 